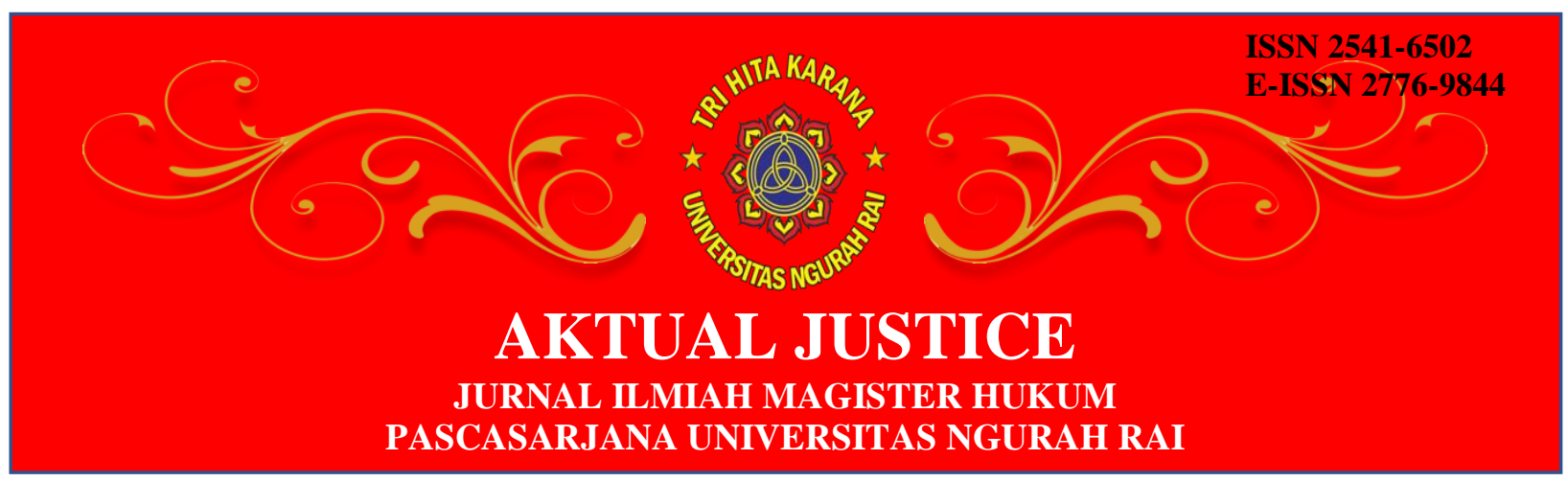

\title{
PERAN KOMISI PENYIARAN INDONESIA DALAM MENGAWASI PENYELENGGARAAN PENYIARAN PADA MASA PANDEMI COVID-19
}

\author{
Ni Putu Noni Suharyanti, ${ }^{1}$ Kadek Endra Setiawan ${ }^{2}$ \\ ${ }^{1}$ Fakultas Hukum Universitas Mahasaraswati Denpasar, \\ E-mail: nonisuharyantifh@unmas.ac.id \\ ${ }^{2}$ Law Office Kadek Endra Setiawan \& Partners, \\ E-mail: endra.setiawan.kadek@gmail.com
}

\begin{abstract}
In order to support the government in overcoming the Covid-19 outbreak, Komisi Penyiaran Indonesia (KPI) has issued several policies related to broadcasting, especially on television. This policy was taken considering that television is still the media with the most audience reach and has a high duplication power in society. Therefore, in every program broadcast to the public, adherence to health protocols is a must. Based on this, it is necessary to examine in depth the role of KPI in overseeing broadcasting and the synergy between Central and Regional KPIs in overseeing broadcasting during the Covid-19 pandemic. The results showed that the KPI in supervising broadcasting during the Covid-19 pandemic played an optimal role in regulating and supervising broadcast content by issuing policies to broadcast the socialization of prevention of the spread of Covid-19 either through Public Service Ads (ILM) or other programs by television and radio. In addition, KPI also issued KPI Decree (KKPI) Number 12 of 2020 concerning Support of Broadcasting Institutions in Efforts to Prevent and Overcome the Spread of Covid-19. Then to follow up on the Circular on news related to the Covid-19 Virus, the Central KPI along with Regional KPI throughout Indonesia conveyed and reminded all Broadcasting Institutions to remain guided by broadcasting rules in broadcasting institutions to convey useful and accountable information.

Keywords: Role, Komisi Penyiaran Indonesia, Broadcasting Institution, Covid-19 Pandemic.

\footnotetext{
Abstrak

Dalam rangka mendukung pemerintah menanggulangi wabah Covid-19, Komisi Penyiaran Indonesia (KPI) telah mengeluarkan beberapa kebijakan terkait penyelenggaraan penyiaran, khususnya di televisi. Kebijakan ini diambil mengingat televisi masih menjadi media dengan jangkauan penonton paling banyak dan
} memiliki daya duplikasi yang tinggi pada masyarakat. Karenanya dalam setiap program yang disiarkan kepada masyarakat, ketaatan terhadap protokol kesehatan merupakan sebuah keharusan. Berdasarkan hal tersebut maka perlu ditelaah secara mendalam terkait peran KPI dalam mengawasi penyelenggaraan
\end{abstract}


penyiaran dan sinergitas antara KPI Pusat dengan Daerah dalam mengawasi penyelenggaraan penyiaran pada masa pandemi Covid-19. Hasil penelitian menunjukkan bahwa KPI dalam mengawasi penyelenggaraan penyiaran pada masa pandemi Covid-19 berperan optimal dalam mengatur dan mengawasi konten siaran dengan menerbitkan kebijakan untuk menyiarkan sosialisasi pencegahan penyebaran Covid-19 baik melalui Iklan Layanan Masyarakat (ILM) ataupun program lainnya oleh televisi dan radio. Disamping itu, KPI juga mengeluarkan Keputusan KPI (KKPI) Nomor 12 tahun 2020 tentang Dukungan Lembaga Penyiaran dalam Upaya Pencegahan dan Penanggulangan Persebaran Covid-19. Kemudian untuk menindaklanjuti Surat Edaran tentang pemberitaan terkait Virus Covid-19, KPI Pusat beserta KPI Daerah di seluruh Indonesia menyampaikan dan mengingatkan ke seluruh Lembaga Penyiaran agar tetap berpedoman pada kaidah-kaidah penayangan di lembaga penyiaran untuk menyampaikan informasi yang bermanfaat dan dapat dipertanggungjawabkan kebenarannya.

Kata Kunci: Peran, Komisi Penyiaran Indonesia, Lembaga Penyiaran, Pandemi Covid-19.

\section{Pendahuluan}

Penyiaran Indonesia membutuhkan sistem yang berkeadilan dalam hal regulasinya dan bermartabat dalam aspek isi siarannya. Regulasi diperlukan karena perkembangan media yang sedemikian marak tentu tidak dapat dibiarkan liar tanpa aturan. Frekuensi merupakan aset terbatas yang penggunaannya dan pemanfaatannya tidak bisa diserahkan kepada "mekanisme alam". Tidak juga kepada mekanisme pasar dan mengharapkan invisible hand akan mengatur dengan sendirinya. Apalagi, frekuensi yang merupakan sarana utama penyiaran pada dasarnya merupakan milik publik yang dikelola oleh negara, bukan individu atau kelompok tertentu. Frekuensi di dunia yang mengalami perkembangan teknologi informasi dan komunikasi ini merupakan aset dengan nilai ekonomis yang tinggi.

$$
\text { Undang-Undang Penyiaran mengamanatkan semangat }
$$

demokratisasi dalam ranah penyiaran. Harapan ini berbanding lurus dengan sistem sosial dan politik Indonesia yang mengarah pada sistem yang demokratis setelah bangsa Indonesia masuk Era Reformasi. Demokratisasi politik merambah pada demokratisisasi penyiaran. Demokratisasi dalam bidang penyiaran secara substansial bermakna berkurangnya atau bahkan hilangnya hegemoni kekuasaan politik 
terhadap dunia penyiaran. Sistem penyiaran demokratis mengandaikan masyarakat diberi kepercayaan untuk mengatur dunia penyiaran. Negara atau pemerintah mempercayakan regulasi penyiaran pada rakyat. Rakyat itulah yang direpresentasikan oleh Komisi Penyiaran Indonesia (KPI).

KPI sebagaimana disebutkan dalam Undang-Undang Republik Indonesia Nomor 32 Tahun 2002 tentang Penyiaran merupakan lembaga negara yang bersifat independen mengatur hal-hal menyangkut penyiaran. Artinya, KPI mempunyai peranan yang sangat signifikan dalam pengaturan dunia penyiaran. Pasal 8 ayat 1 Undang-Undang Penyiaran menyebutkan "KPI sebagai wujud peran serta masyarakat berfungsi mewadahi aspirasi serta mewakili kepentingan masyarakat akan penyiaran". Ini menandakan bahwa KPI ada bukan tanpa alasan, namun atas dasar yang jelas yakni mewakili masyarakat.

Demokratisasi dalam ranah penyiaran berisi freedom of the press atau kebebasan pers. Freedom of the press, merupakan hak yang berisi kebebasan pers untuk menyiarkan sesuatu kepada khalayak tanpa intervensi dan kekangan. Kebebasan pers merupakan kebebasan bagi pers untuk melaksanakan kegiatannya dan mejadi nafas serta ruh dalam demokrasi dan terjadi dalam sistem pemerintahan yang demokratis. Hanya saja, kebebasan pers dan penyiaran itu tidak boleh tereduksi dengan perilaku kebebasan yang merugikan. Kebebasan pers itu diperkenankan dalam kerangka positif, bukan kebebasan "sekehendak sendiri" yang memarginalkan kepentingan publik. Terlebih lagi, lembaga penyiaran lebih dari sekedar lembaga pers, karena banyak program siaran yang bukan merupakan ranah pers atau jurnalistik.

Demokratisasi penyiaran juga bisa dimaknai dengan adanya diversity of content (keragaman isi), diversity of ownership (keragaman kepemilikan) dan diversity of voice (keragaman pendapat dan suara). Artinya, monopoli kepemilikan media seharusnya tidak diperkenankan. 
Sementara isi siaran seharusnya tidak boleh lagi seragam dan bersifat sentralistik. Untuk itulah, KPI merumuskan dan menetapkan Pedoman Perilaku Penyiaran dan Standar Program Siaran (P3SPS) yang seharusnya menjadi acuan standar bagi penyiaran di Indonesia.

P3SPS merupakan parameter mengenai apa yang boleh dan tidak boleh disiarkan, bukan dalam kerangka mengekang kebebasan pers tetapi untuk memartabatkan isi siaran. Tidak semua hal pantas disiarkan dan disajikan kepada publik. Sebagai wakil publik dalam urusan penyiaran, KPI komitmen mengawal media penyiaran tetap konsisten dalam menjalankan fungsinya, sebagai sumber informasi (yang layak dan benar), pendidikan, hiburan (yang sehat), perekat serta kontrol sosial, yang merupakan tanggung jawab sosial yang seharusnya tetap diusung media penyiaran.

Pandemi yang melanda dunia akibat Corona Virus Disease-19 (Covid19) telah mengharuskan masyarakat melakukan adaptasi kebiasaan baru guna menekan jumlah penyebaran virus tersebut. Selain menetapkan protokol kesehatan yakni mencuci tangan, menjaga jarak dan mengenakan masker (3M), pemerintah Indonesia juga membuat berbagai batasan sosial guna mengurangi mobilitas penduduk, yakni dengan menetapkan kebijakan bekerja, belajar dan beribadah dari rumah.

Dalam rangka mendukung pemerintah menanggulangi wabah Covid-19, Komisi Penyiaran Indonesia (KPI) telah mengeluarkan beberapa kebijakan terkait penyelenggaraan penyiaran, khususnya di televisi. Kebijakan ini diambil mengingat televisi masih menjadi media dengan jangkauan penonton paling banyak dan memiliki daya duplikasi yang tinggi pada masyarakat. Karenanya dalam setiap program yang disiarkan kepada masyarakat, ketaatan terhadap protokol kesehatan merupakan sebuah keharusan. 
Kedisiplinan lembaga penyiaran terhadap protokol kesehatan menjadi perhatian penting dari berbagai pemangku kepentingan yang menangani penanggulangan Covid-19. Penegakan protokol kesehatan tidak akan efektif jika di televisi masih menyiarkan perilaku abai terhadap kewajiban mengenakan masker, mencuci tangan dan menjaga jarak.

Sepanjang Januari 2021, KPI menemukan 37 tayangan televisi yang diduga melanggar protokol kesehatan yang bersumber dari 11 stasiun televisi. Sebanyak 36 tayangan berasal dari hasil tim pemantauan isi siaran, sedangkan 1 tayangan berasal dari pengaduan publik yang disampaikan ke KPI dan telah diverifikasi. Dari 37 tayangan ini, pelanggaran protokol kesehatan yang dilakukan didominasi dengan tidak mengenakan masker dan pelindung wajah, selain itu didapati juga tayangan yang tidak memperhatikan jarak fisik atau social distancing. ${ }^{1}$

Tayangan yang berpotensi melanggar protokol kesehatan tersebut didominasi oleh program hiburan seperti variety show. Namun demikian, KPI juga mencatat program lain yang turut melakukan pelanggaran seperti program religi dan talkshow. Oleh karena itu, penting untuk ditelaah secara mendalam terkait peran KPI dalam mengawasi penyelenggaraan penyiaran di masa pandemi Covid-19 khususnya pada program siaran pertelevisian serta sinergitas antara KPI Pusat dan Daerah dalam mengawasi penyelengaraan penyiaran pada masa pandemi Covid-19.

\section{Metode Penelitian}

\subsection{Jenis Penelitian}

1 kpi.go.id. (2021). Evaluasi Kepatuhan Televisi Atas Protokol Kesehatan Dalam Penyelenggaraan Penyiaran di Masa Pandemi Covid-19: Januari 2021. Available from http://www.kpi.go.id/index.php/id/umum/38-dalam-

negeri?detail5=936\&detail3=76\&start=70. Diakses 10 Mei 2021. 
Ronny Hanitijo Soemitro dalam Mukti Fajar ND dan Yulianto Achmad mengemukakan bahwa "penelitian hukum dapat dibedakan antara; penelitian hukum normatif atau penelitian hukum doktrinal, yaitu penelitian hukum yang menggunakan sumber data sekunder atau data yang diperoleh melalui bahan-bahan kepustakaan, dan penelitian hukum empiris atau penelitian hukum sosiologis, yaitu penelitian hukum yang memperoleh datanya dari data primer atau data yang diperoleh langsung dari masyarakat". 2

Berdasarkan pembagian penelitian hukum di atas, maka jenis penelitian yang digunakan dalam penelitian ini adalah penelitian hukum empiris. Penelitian tentang peran KPI dalam mengawasi penyelenggaraan penyiaran pada masa pandemi Covid-19 di Indonesia berangkat dari pemikiran bahwa dengan masih banyaknya pelanggaran protokol kesehatan oleh beberapa penyelenggara siaran televisi menuntut KPI harus lebih bekerja ekstra untuk tetap mengawasi program siaran sehingga lembaga penyiaran tetap dapat menayangkan siaran yang berkualitas dan memberikan edukasi serta manfaat yang baik di masyarakat terlebih lagi situasi saat ini sedang tidak kondisif akibat masih merebaknya penyebaran virus Covid-19.

\subsection{Data dan Sumber Data}

Data yang dipergunakan dalam penelitian ini meliputi data primer dan data sekunder. Berkenaan dengan hal tersebut, Halim H.S dan Erlies Septiana mengemukakan bahwa "data primer adalah data yang berasal dari data lapangan, dimana data itu diperoleh baik dari responden maupun informan, sedangkan data sekunder adalah data yang tingkatannya kedua, bukan yang utama". ${ }^{3}$ Adapun sumber data primer dalam penelitian ini

2 ND, Mukti Fajar \& Achmad. Y. (2007). Dualisme Penelitian Hukum. Yogyakarta: Fakultas Hukum Universitas Muhammadiyah. h. 109.

${ }^{3}$ HS, H. Salim \& Nurbani. E.S. (2013). Penerapan Teori Hukum Pada Penelitian Tesis dan Disertasi. Jakarta: PT RajaGrafindo Persada. h. 25. 
berasal dari hasil pengamatan (observasi) melalui media online terkait dengan perkembangan kasus pelanggaran penyelenggaraan penyiaran oleh media televisi di Indonesia. Sedangkan data sekunder dalam penelitian ini adalah data yang bersumber dari penelitian kepustakaan, dalam artian data tidak diperoleh secara langsung dari sumber pertamanya, melainkan bersumber dari data-data yang sudah terdokumenkan dalam bentuk bahan-bahan hukum, baik bahan hukum primer, bahan hukum sekunder, dan bahan hukum tersier.

Adapun sumber data sekunder dalam penelitian ini yaitu sebagai berikut:

a. Bahan Hukum Primer

Bahan hukum primer terdiri dari beberapa peraturan perundangundangan yang terkait dengan penelitian ini, yaitu Undang-Undang Republik Indonesia Nomor 32 Tahun 2002 tentang Penyiaran, Peraturan Komisi Penyiaran Indonesia Nomor 01/P/KPI/02/2012 tentang Pedoman Perilaku Penyiaran, Peraturan Komisi Penyiaran Indonesia 02/P/KPI/03/2012 tentang Standar Program Siaran, Surat Edaran Komisi Penyiaran Indonesia Pusat Nomor 123/K/KPI/31.2/03/2020 tentang Penyiaran Wabah Corona, Keputusan Komisi Penyiaran Indonesia Pusat Nomor 12 Tahun 2020 tentang Dukungan Lembaga Penyiaran Dalam Upaya Pencegahan dan Penanggulangan Persebaran Covid-19.

b. Bahan Hukum Sekunder

Mengenai bahan hukum sekunder, bahan hukum sekunder yang digunakan dalam penelitian ini terdiri dari literatur atau buku-buku hukum dan juga non hukum yang berkaitan dengan penelitian ini, jurnal hukum baik jurnal nasional maupun jurnal internasional, hasil- 
hasil penelitian, artikel atau karya tulis hukum yang termuat di media internet, dan pendapat para pakar hukum.

c. Bahan Hukum Tersier

Dalam penelitian ini digunakan juga bahan hukum tersier seperti kamus hukum. Berkaitan dengan kamus hukum, Maureen F. Fitzgerald mengemukakan bahwa "legal dictionaries define legal terms and common words with special legal meaning" 4 (kamus hukum mendefinisikan istilah hukum dan kata-kata umum dengan arti hukum khusus). Oleh karena itu, dalam penelitian ini peneliti menggunakan kamus hukum agar mempermudah dalam mengartikan istilah-istilah khusus yang dipergunakan dalam hukum.

\subsection{Teknik Pengumpulan Data}

Adapun teknik pengumpulan data yang digunakan dalam penelitian ini yaitu:

a. Teknik Studi Dokumen

Teknik studi dokumen merupakan teknik awal yang digunakan dalam setiap penelitian ilmu hukum, baik dalam penelitian normatif maupun penelitian hukum empiris. Teknik studi dokumen ini dilakukan dengan cara mengumpulkan bahan-bahan hukum baik primer, sekunder, dan tersier yang terkait dengan penelitian ini.

b. Teknik Observasi

Observasi adalah teknik pengumpulan data yang dilakukaan melalui sesuatu pengamatan, dengan disertai pencatatan-pencatatan terhadap keadaan atau prilaku objek sasaran. ${ }^{5}$ Sedangkan menurut Sutrisno Hadi metode observasi diartikan sebagaipengamatan, pencatatan dengan sistematis fenomena-fenomena yang diselidiki. ${ }^{6}$

${ }^{4}$ Fitzgerald, M.F. (2007). Legal Problem Solving : Reasoning, Research, and Writing. Edisi Keempat. Canada: LexisNexis. h. 111.

${ }^{5}$ Narbuko, C. dkk. (1997). Metodologi Penelitian. Jakarta: Bumi Aksara. h. 76.

${ }^{6}$ Hadi, S. (2002). Metodologi Reserch. Yogyakarta: Andi Ofset. Edisi Refisi. h. 136. 


\subsection{Teknik Pengolaham dan Analisis Data}

Teknik pengolahan data adalah kegiatan merapikan data hasil dari pengumpulan data sehingga siap untuk digunakan lalu kemudian dianalisis. Model analisis yang digunakan dalam penelitian ini adalah model analisis data kualitatif. Keseluruhan data-data yang terkait dengan peran Komisi Penyiaran Indonesia dalam mengawasi penyelenggaraan penyiaran pada masa pandemi Covid-19 akan diolah dan dianalisis dengan cara menyusun data secara sistematis dan selektif. Setelah melakukan pengolahan secara sistematis dan selektif, maka data tersebut akan dijabarkan secara deskriptif analitis dalam bentuk uraian-uraian yang disertai dengan penjelasan teori-teori hukum, sehingga nantinya dapat diperoleh gambaran serta kesimpulan yang jelas dari permasalahan yang diteliti.

\section{Hasil dan Pembahasan}

\subsection{Peran Komisi Penyiaran Indonesia (KPI) Dalam} Mengawasi Penyelenggaraan Penyiaran Pada Masa Pandemi Covid19

Penyiaran adalah kegiatan penyelenggaraan siaran radio maupun televisi, yang diselenggarakan oleh organisasi penyiaran radio atau televisi. ${ }^{7}$ Pada Pasal 1 butir 2 dalam Ketentuan Umum Undang-Undang Republik Indonesia Nomor 32 Tahun 2002 tentang Penyiaran, memberikan definisi khusus penyiaran sebagai kegiatan pemancarluasan siaran melalui sarana pemancar dan/atau media lainnya untuk dapat diterima secara serentak dan bersamaan oleh masyarakat dengan perangkat penerima siaran. Definisi khusus yang dimaksudkan disini adalah berkaitan dengan fungsi regulasi yang diamanatkan oleh Undang-Undang tersebut, sehingga

7 Rachman, H. A. (2016). Dasar-Dasar Penyiaran. Pekanbaru: Unri Press. h. 15. 
definisinya dibatasi mulai dari kegiatan pemancarluasan siaran, yang yang tentunya telah menggunakan ruang publik.

Dengan demikian, di ruang publik ini, penyiaran telah menggunakan spektrum frekuensi penyiaran telah melangsungkan proses komunikasi massa dan sebagainya. Sementara proses produksi siaran tersebut seperti produk paket siaran belum masuk wilayah publik atau masih bersifat intern stasiun penyiaran bersangkutan dan karenanya tidak termasuk dalam pengaturan UU tersebut. Oleh karena itu, stasiun penyiaran bebas menentukan apakah paket itu diproduksi sndiri atau dari rumah produksi. Tetapi bila bahan content itu kemudian disiarkan yang berarti masuk ke ruang publik, dia harus mengikuti aturan tentang content yang disusun oleh KPI. ${ }^{8}$

Dalam rangka menjalankan fungsinya KPI memiliki kewenangan (otoritas) menyusun dan mengawasi berbagai peraturan penyiaran yang menghubungkan antara lembaga penyiaran, pemerintah dan masyarakat. Pengaturan ini mencakup semua daur proses kegiatan penyiaran, mulai dari tahap pendirian, operasionalisasi, pertanggungjawaban dan evaluasi. Dalam melakukan kesemua ini, KPI berkoordinasi dengan pemerintah dan lembaga negara lainnya, karena spektrum pengaturannya yang saling berkaitan. Ini misalnya terkait dengan kewenangan yudisial dan yustisial karena terjadinya pelanggaran yang oleh Undang-Undang Penyiaran dikategorikan sebagai tindak pidana. Selain itu, KPI juga berhubungan dengan masyarakat dalam menampung dan menindaklanjuti segenap bentuk apresiasi masyarakat terhadap lembaga penyiaran maupun terhadap dunia penyiaran pada umumnya.

Dalam menjalankan fungsi, tugas, wewenang dan kewajibannya, KPI Pusat diawasi oleh Dewan Perwakilan Rakyat Republik Indonesia, dan

${ }^{8}$ Fachruddin, A \& Hidajanto. D. (2013). Dasar-Dasar Penyiaran di Indonesia. Jakarta: Kencana. h. 44. 
KPI Daerah diawasi oleh Dewan Perwakilan Rakyat Daerah Provinsi. KPI didukung secara operasional oleh suatu Sekretariat yang dibiayai oleh negara dimana Sekretariat pada KPI Daerah berdasarkan Surat Keputusan menteri Dalam Negeri adalah setingkat Satuan Kerja Perangkat Daerah (SKPD). Berikut ini adalah kewenangan, tugas dan kewajiban KPI dalam rangka melakukan pengaturan penyiaran.

a. Wewenang

1). Menetapkan standar program siaran;

2). Menyusun peraturan dan menetapkan pedoman perilaku penyiaran;

3). Mengawasi pelaksanaan peraturan dan pedoman perilaku penyiaran serta standar program siaran;

4). Memberikan sanksi terhadap pelanggaran peraturan dan pedoman perilaku penyiaran serta standar program siaran;

5). Melakukan koordinasi dan/atau kerjasama dengan Pemerintah, lembaga penyiaran, dan masyarakat.

b. Tugas dan Kewajiban

1). Menjamin masyarakat untuk memperoleh informasi yang layak dan benar sesuai dengan hak asasi manusia;

2). Ikut membantu pengaturan infrastruktur bidang penyiaran;

3). Ikut membangun iklim persaingan yang sehat antarlembaga penyiaran dan industri terkait;

4). Memelihara tatanan informasi nasional yang adil, merata, dan seimbang;

5). Menampung, meneliti, dan menindaklanjuti aduan, sanggahan, serta kritik dan apresiasi masyarakat terhadap penye-lenggaraan penyiaran;

6). Menyusun perencanaan pengembangan sumber daya manusia yang menjamin profesionalitas di bidang penyiaran. 
Tugas dan kewenangan lembaga yang dibentuk oleh UndangUndang Penyiaran hanya mengawasi siaran televisi dan radio. KPI tidak memiliki kewenangan melakukan sensor terhadap sebuah tayangan dan melarangnya. Pengawasannya pun baru dapat berjalan setelah tayang. Jadi, sebelum tayangan tersebut disiarkan di lembaga penyiaran adalah tugas lembaga sensor film dan internal lembaga penyiaran tersebut yang memiliki kewenangan sensor. KPI tidak melakukan pengawasan terhadap konten media sosial. Pengawasan konten di media sosial masih menjadi tugas lembaga lain karena di dalam Undang-Undang Penyiaran tidak mencakup hal itu.

Sebagai regulator penyiaran yang bertugas mengatur dan mengawasi setiap konten siaran, KPI telah menerbitkan kebijakan untuk menyiarkan sosialisasi pencegahan penyebaran Covid-19 baik melalui Iklan Layanan Masyarakat (ILM) atau pun program lainnya oleh televisi dan radio. KPI juga mengeluarkan Keputusan KPI (KKPI) Nomor 12 tahun 2020 tentang Dukungan Lembaga Penyiaran dalam Upaya Pencegahan dan Penanggulangan Persebaran Covid-19. Berdasarkan KKPI tersebut, KPI menetapkan 7 (tujuh) hal yang menjadi parameter kepatuhan program siaran dalam menjalankan protokol kesehatan, yakni sebagai berikut:

1. Jaga jarak 1-2 meter;

2. Menggunakan masker dan/atau pelindung wajah;

3. Tidak melakukan adegan kontak fisik;

4. Menayangkan Video Tapping (rekaman) atau penyematan informasi bahwa sebelum siaran dimulai lembaga penyiaran telah melakukan sterilisasi ruangan, peralatan dan perlengkapan shooting serta protokol kesehatan bagi para kru, talen, pembawa acara, maupun narasumber;

5. Menghadirkan orang di dalam studio dengan tidak melebihi $25 \%$ dari kapasitas ruangan; 
6. Visualisasi adegan news anchor membuka masker pada saat memulai membaca berita dan mengakhirinya dengan menutup masker.

KPI Pusat juga telah melakukan imbauan dan evaluasi muatan siaran di masa pandemi Covid-19. Dimana dalam imbauan tersebut disebutkan bahwa sesuai Instruksi Presiden, Keputusan Menteri Komunikasi dan Informatika Republik Indonesia Nomor 159 Tahun 2020 tentang Upaya Penanganan Corona Virus Disease (COVID-19) Melalui Dukungan Sektor Pos dan Informatika dan Surat Edaran KPI Pusat Nomor 156/K/KPI/31.2/03/2020 tentang Peran Serta Lembaga Penyiaran dalam Penanggulangan Persebaran Wabah Corona, dan memperhatikan 239 aduan masyarakat terkait perlindungan anak dan remaja sepanjang bulan Maret 2020 serta hasil kajian pemantauan maka KPI Pusat meminta: ${ }^{9}$

a. Komitmen lembaga penyiaran untuk lebih masif menyampaikan informasi pencegahan dan penanggulangan Covid-19 terutama tindakan social/physical distancing melalui ILM di setiap program yang disiarkan atau setiap jam sekali.

b. Memberikan contoh pelaksanaan social/physical distancing dengan tidak memuat program yang menampilkan visualisasi massa/penonton, baik secara live, tapping, maupun rekayasa editing kecuali diinformasikan secara jelas bahwa tayangan tersebut rekaman/recorded/re-run dalam bentuk running text atau caption di sepanjang penayangan program.

c. Menerapkan protokol pencegahan dan penanganan keamanan dalam bentuk physical distancing bagi host/presenter, kru penyiaran, jurnalis, narasumber, dan pendukung acara lainnya baik di dalam maupun di luar studio.

${ }^{9}$ kpi.go.id. (2021). Imbauan dan Evaluasi Muatan Siaran di Masa Pandemi Covid-19. Available at http://www.kpi.go.id/index.php/id/edaran-dan-sanksi/35656-imbauandan-evaluasi-muatan-siaran-di-masa-pandemi-covid-19, diakses 14 Mei 2021. 
d. Mengingatkan kepada seluruh lembaga penyiaran agar patuh pada ketentuan terkait perlindungan anak-anak dan remaja dengan:

1). Memperhatikan ketersediaan program bagi anak pada pukul 05.00 hingga pukul 18.00 WIB dengan muatan, gaya penceritaan dan tampilan yang sesuai dengan perkembangan psikologis anakanak dan remaja;

2). Selektif memilih materi tayangan agar tidak menstimulasi anak melakukan tindakan yang tidak semestinya ditiru atau dianggap lazim/lumrah seperti diberitakan akhir-akhir ini yaitu menikah pada usia muda, eksploitasi pernikahan dini, pengungkapan konflik rumah tangga, dan sebagainya;

3). Menampilkan konflik dan aksi/adegan kekerasan, bullying dalam rumah tangga, sekolah, dan lingkungan sosial lainnya;

4). Membatasi adegan percintaan dan perselingkuhan.

e. Meminta lembaga penyiaran agar memperbanyak program siaran bertema pendidikan dan pembelajaran untuk membantu proses belajar mengajar anak di rumah.

f. Mengedepankan perbincangan yang konstruktif dan solutif dalam penanganan persebaran Covid-19 sebagai wujud kepedulian bersama.

Pada Februari 2021, melalui situs resminya KPI mencatat dan mempublikasikan beberapa program siaran yang berpotensi melanggar protokol kesehatan. Adapun program siaran dimaksud yakni:

Tabel 1.

Data Daftar Program Siaran yang Berpotensi Melanggar Protokol Kesehatan

\begin{tabular}{|c|l|c|c|l|}
\hline \multirow{2}{*}{ No } & \multirow{2}{*}{ Lembaga Penyiaran } & \multicolumn{3}{|c|}{ Jumlah Program Siaran Dugaan Pelanggaran } \\
\cline { 3 - 5 } & & Temuan & Aduan & Keterangan \\
\hline 1 & Indosiar & 1 & - & $\begin{array}{l}\text { Semarak } \\
\text { Indosiar A }\end{array}$ \\
\hline 2 & Kompas Tv & 3 & - & $\begin{array}{l}\text { a. Suci IX } \\
\text { b. Bincang Kita } \\
\text { c. Home Sweet } \\
\text { Home }\end{array}$ \\
\hline
\end{tabular}


ISSN : 2541-6502

E-ISSN : 2776-9844

\begin{tabular}{|c|c|c|c|c|}
\hline 3 & Metro & 2 & - & \begin{tabular}{|l} 
a. Sirah \\
Nabawiyah \\
b. Susi Cek \\
Ombak
\end{tabular} \\
\hline 4 & MNC TV & 1 & - & Siraman Qolbu \\
\hline 5 & NET TV & 2 & - & $\begin{array}{l}\text { a. In The Kost } \\
\text { b. Peristawa }\end{array}$ \\
\hline 6 & RCTI & 3 & - & $\begin{array}{l}\text { a. Ok Chef } \\
\text { b. Dahsyatnya } \\
2021 \\
\text { c. Minta Tolong } \\
\text { (New) }\end{array}$ \\
\hline 7 & RTV & 1 & - & Caca Marica \\
\hline 8 & SCTV & 1 & - & $\begin{array}{l}\text { Waktu Indonesia } \\
\text { Belanja } \\
\text { Tokopedia }\end{array}$ \\
\hline 9 & Trans 7 & 2 & - & $\begin{array}{ll}\text { a. Bukan Bisik- } \\
\text { Bisik } \\
\text { b. OOTD } \\
\text { Obrolan Of } \\
\text { The Day }\end{array}$ \\
\hline 10 & Trans TV & 8 & 1 & $\begin{array}{ll}\text { a. Santuy Malam } \\
\text { b. Celebrity On } \\
\text { Vacation } \\
\text { c. Nih Kita Kepo } \\
\text { d. Keluarga Bos } \\
\text { Que } \\
\text { e. Obrolan } \\
\text { Terupdate } \\
\text { Wadidaw } \\
\text { f. Hangout With } \\
\text { Andre } \\
\text { g. Uwu Moment } \\
\text { h. Pagi-Pagi } \\
\text { Ambyaaarrr } \\
\text { (Pengaduan) }\end{array}$ \\
\hline 11 & TV One & 5 & - & $\begin{array}{ll}\text { a. } & \text { One Pride } \\
& \text { MMA } \\
\text { b. One Pest } \\
\text { c. Saatnya } \\
\text { Perempuan } \\
\text { Bicara } \\
\text { d. Rumah } \\
\text { Mamah Dedeh } \\
\text { e. Apa Kabar } \\
\text { Indonesia } \\
\text { Malam } \\
\end{array}$ \\
\hline & JUMLAH & 29 & 1 & 30 \\
\hline
\end{tabular}




\section{Sumber: kpi.go.id}

Tayangan yang berpotensi melanggar protokol kesehatan ini didominasi oleh program hiburan seperti variety show. Namun demikian, KPI juga mencatat program lain yang turut melakukan pelanggaran seperti program religi dan talkshow. Evaluasi KPI atas kepatuhan terhadap dukungan lembaga penyiaran dalam upaya pencegahan dan penanggulangan persebaran Covid-19, tidak termasuk pada program siaran film, sinetron dan tayangan yang disiarkan ulang (re-run) yang diproduksi sebelum pandemi Covid-19. Atas temuan potensi pelanggaran ini, KPI akan menindaklanjuti dalam Rapat Pleno Penjatuhan Sanksi yang dilakukan secara regular. Melalui Rapat Pleno akan diputuskan jenis sanksi yang dijatuhkan pada masing-masing program siaran yang terbukti melakukan pelanggaran.

Usaha menuntaskan pandemi Covid-19 membutuhkan kerja sama segenap pihak, termasuk penyelenggara penyiaran yang senantiasa menghadirkan program yang menjadi contoh dan dengan mudah ditiru oleh publik. Namun perlu di garis bawahi kembali bahwa KPI tidak bisa melakukan interupsi terhadap lembaga penyiaran. KPI hanya melakukan pengawasan terhadap frekuensi yang digunakan lembaga penyiaran tersebut. Ketika acara telah ditayangkan oleh lembaga penyiaran dan terjadi pelanggaran aturan, di sanalah posisi KPI bertindak. Namun dalam hal ini KPI tetap memiliki kewajiban untuk ikut mengembangkan industri penyiaran di tanah air. Kewajiban tersebut selaras dengan cara KPI mendorong peningkatan kualitas tayangan di lembaga penyiaran.

\subsection{Sinergitas Komisi Penyiaran Indonesia (KPI) Pusat dan Daerah dalam Mengawasi Penyelenggaraan Penyiaran Pada Masa Pandemi Covid-19}


KPI terdiri atas KPI Pusat yang dibentuk di tingkat pusat dan KPI Daerah dibentuk di tingkat provinsi. Anggota KPI Pusat berjumlah 9 (sembilan) orang dan KPI Daerah berjumlah 7 (tujuh) orang. Masa jabatan keanggotaan KPI Pusat dan KPI Daerah adalah 3 (tiga) tahun dan dapat dipilih kembali hanya untuk satu kali masa jabatan berikutnya. Secara umum tata hubungan antara KPI Pusat dan KPI Daerah bersifat koordinatif tidak struktural, sehingga Undang-Undang Penyiaran menyerahkan mekanismenya diatur dalam Peraturan KPI. Sesuai dengan Peraturan KPI tentang Kelembagaan maka tata hubungan antar KPI Pusat dan KPI Daerah adalah sebagai berikut:

a. KPI Pusat bertindak sebagai koordinator bagi pelaksanaan wewenang, tugas, fungsi, dan kewajiban yang melibatkan KPI Pusat dan KPI Daerah, yang bersifat lintas daerah/wilayah, dan bersifat nasional.

b. KPI Pusat bertindak sebagai mediator dan fasilitator komunikasi dan koordinasi KPI serta antara KPI dan Pemerintah Pusat.

c. KPI Pusat bertindak sebagai mediator komunikasi dan koordinasi antara KPI Daerah dan Pemerintah Daerah.

d. Dalam melaksanakan fungsi, wewenang, tugas, dan kewajibannya, KPI Daerah melakukan koordinasi dengan KPI Pusat.

e. KPI Pusat dapat melakukan dekonsentrasi anggaran dan kegiatan ke KPI Daerah seluruh Indonesia.

f. KPI Pusat memfasilitasi terbentuknya Sekretariat KPI Daerah.

g. Untuk daerah yang belum terbentuk KPI Daerah, segala kewenangan penyiaran ada pada KPI Pusat.

Sekalipun saluran informasi sudah demikian berlimpah baik melalui media konvensional ataupun media sosial dan platform digital lainnya, media televisi dan radio masih menjadi saluran informasi yang paling dipercaya oleh publik. Untuk itu, seluruh lembaga penyiaran tidak tergoda menyebar info yang belum pasti yang bersumber dari media sosial. Disiplin 
verifikasi dan konfirmasi ulang dari setiap informasi harus tetap dilakukan untuk mencegah masyarakat menelan berita bohong dan menyesatkan. Jangan sampai masyarakat dilanda kepanikan karena informasi sesat yang disebar media. Validitas informasi ini tidak hanya untuk program-program berita, namun juga program lainnya seperti infotainment, talkshow ataupun reality show. Pernyataan host dan konten harus terkontrol dengan baik.

Sebagai sebuah lembaga independen di Indonesia yang kedudukannya setingkat dengan lembaga negara lainnya yang berfungsi sebagai regulator penyelenggaraan penyiaran di Indonesia, maka KPI Pusat dan Daerah bersinergi dalam mengawasi penyelenggaraan penyiaran. Konsep sinergitas justru muncul dari adanya kebutuhan untuk membangun masyarakat atas dasar kerjasama yang saling menguntungkan dan dilandasi pemikiran-pemikiran yang rasional, terbuka, dan demokratis. $^{10}$

Menanggapi Surat Edaran KPI Pusat Nomor 123/K/KPI/31.2/03/2020 tentang Penyiaran Wabah Corona, dimana dalam menindaklanjuti pemberitaan terkait Wabah Virus Corona atau 2019 Novel Coronavirus (Covid-19), KPI Pusat beserta KPID di seluruh Indonesia menyampaikan dan mengingatkan ke seluruh Lembaga Penyiaran agar tetap berpedoman pada kaidah-kaidah penayangan di lembaga penyiaran untuk menyampaikan informasi yang bermanfaat dan dapat dipertanggungjawabkan kebenarannya.

Maksud dan tujuan Surat Edaran ini adalah agar lembaga penyiaran senantiasa mengingat dan berpedoman pada kaidah-kaidah penayangan di

10 Firmansyah, M. I. (2016). Studi Deskriptif Tentang Sinergitas Kewenangan Antara BPJS Kesehatan dengan Organisasi Profesi Dalam Penyediaan Layanan Kesehatan di Kota Surabaya. Jurnal Kebijakan dan Manajemen Publik, 4 (2): h.146-156. 
lembaga penyiaran. Adapun dalam surat edaran tersebut ditegaskan beberapa hal sebagai berikut:

a. Memberitakan/menginformasikan wabah Virus Corona dengan hatihati, tidak spekulatif, dan tidak menimbulkan kepanikan masyarakat di semua program yang disiarkan termasuk pernyataan host/reporter/penyiar; Menggunakan diksi (pilihan kata) dan pembawaan presenter/reporter/host secara tepat dan tidak terkesan mendramatisir atau menakut-nakuti agar tidak menimbulkan persepsi publik yang menyebabkan kepanikan;

b. Menyampaikan bahwa pemerintah telah turun tangan menangani wabah Virus Corona (Covig-19) dan menyebutkan hotline service Kemkes RI (081212123119 atau 021-5210411) atau hotline service masing-masing daerah dan Rumah Sakit rujukan untuk penanganan wabah Virus Corona di masing-masing wilayah (lihat website Kemkes RI berikut ini http://infeksiemerging.kemkes.go.id/ atau http:// sehatnegeriku. kemke s. go. id /);

c. Menggunakan sumber informasi tentang Virus Corona dari sumber yang dapat dipertanggungjawabkan dan terkonfirmasi serta tidak menyiarkan informasi dari media sosial kecuali informasi tersebut telah terkonfirmasi kebenarannya;

d. Menghadirkan narasumber wawancara yang kredibel dan menyampaikan materi wawancara secara positif dalam pembahasan wabah Virus Corona;

e. Tidak menyebutkan identitas pasien dan tidak mengeksploatasi lingkungan serta warga sekitar penderita;

f. Menyampaikan data-data tentang wabah Virus Corona secara berimbang. Jika hendak menyampaikan angka kematian harus diikuti dengan angka (persentase) kesembuhan; 
g. Menayangkan/menyiarkan ILM tentang wabah Virus Corona yang berisi: cara persebaran, gejala, langkah pencegahan dan penanganan dini, hotline service pemerintah dan di daerah, serta RS yang ditunjuk untuk penanganan;

h. Menyampaikan peringatan bahwa pihak-pihak yang memanfaatkan situasi terkait wabah Virus Corona (spekulan masker dan hand sanitizer) diancam penjara 6 tahun dan maksimal denda Rp 4 milyar sebagaimana disebutkan dalam Undang-Undang Republik Indonesia Nomor 24 Tahun 2007 tentang Penanggulangan Bencana.

Pada Surat Edaran tersebut juga telah ditegaskan juga apabila dalam hal lembaga penyiaran tidak melaksanakan beberapa ketentuan yang tercantum dalam Surat Edaran, maka akan ditindak lanjuti sesuai kewenangan KPI sebagaimana Peraturan KPI Nomor 01/P/KPI/03/2012 tentang Pedoman Perilaku Penyiaran dan Peraturan KPI Nomor 02/P/KPI/03/2012 tentang Standar Program Siaran.

Pesatnya perkembangan teknologi sekarang, berbanding lurus dengan pertumbuhan lembaga penyiaran di Indonesia. Hal ini tentunya menjadi tantangan tersendiri bagi masyarakat dalam menyaring setiap informasi dan muatan siaran yang sesuai dengan kebutuhan. Namun pada prinsipnya, jika masyarakat terlibat maka pengawasan terhadap lembaga penyiaran akan lebih baik. Bahkan akan mendorong dihasilkannya produk siaran yang sehat dan lebih berkualitas.

Masyarakat memiliki peran penting dalam menekan dampak negatif siaran televisi. Salah satunya dimulai dengan adanya ketahanan keluarga dalam memahami penggunaan media, baik itu televisi dan radio. Untuk itulah, dibutuhkan peran aktif dari masyarakat agar muatan siaran senantiasa selalu sehat dan bermanfaat. KPI tidak dapat bekerja sendiri dalam mewujudkan penyiaran yang sehat dan bermartabat. Peran serta 
masyarakat mutlak dibutuhkan untuk ikut mengawasi konten siaran agar bersih dari muatan pelanggaran.

Masyarakat dapat mengambil peran dengan tetap kritis pada setiap muatan isi siaran. Jika ada tayangan yang dirasa tidak sesuai dengan norma kesopanan, budaya, adat istiadat ataupun norma agama, maka masyarakat dapat segera melaporkannya kepada KPI. Masukan dan pendapat masyarakat ini, selain berguna untuk ditindaklanjuti oleh KPI, juga bermanfaat bagi pengelola televisi dan radio untuk memperbaiki mutu siaran.

\section{Kesimpulan}

Berdasarkan atas latar belakang, rumusan masalah yang diperoleh serta pembahasan yang dilakukan, maka kesimpulan yang dapat dikemukakan yaitu sebagai berikut:

a. KPI dalam mengawasi penyelenggaraan penyiaran pada masa pandemi Covid-19 berperan optimal dalam mengatur dan mengawasi konten siaran dengan menerbitkan kebijakan untuk menyiarkan sosialisasi pencegahan penyebaran Covid-19 baik melalui Iklan Layanan Masyarakat (ILM) atau pun program lainnya oleh televisi dan radio. Disamping itu, KPI juga mengeluarkan Keputusan KPI (KKPI) Nomor 12 tahun 2020 tentang Dukungan Lembaga Penyiaran dalam Upaya Pencegahan dan Penanggulangan Persebaran Covid-19.

b. KPI Pusat bersinergi aktif dengan KPI Daerah dalam mengawasi penyelenggaraan penyiaran di masa pandemi Covid-19 dimana dalam menindaklanjuti Surat Edaran tentang pemberitaan terkait Virus Covid-19, KPI Pusat beserta KPI Daerah di seluruh Indonesia menyampaikan dan mengingatkan ke seluruh Lembaga Penyiaran agar tetap berpedoman pada kaidah-kaidah penayangan di lembaga 
penyiaran untuk menyampaikan informasi yang bermanfaat dan dapat dipertanggungjawabkan kebenarannya.

\section{DAFTAR PUSTAKA}

\section{Buku}

Fachruddin, A \& Hidajanto D. (2013). Dasar-Dasar Penyiaran di Indonesia. Jakarta: Kencana.

Fitzgerald, M. F. (2007). Legal Problem Solving : Reasoning, Research, and Writing. Edisi Keempat. Canada: LexisNexis.

Hadi, S. (2002). Metodologi Reserch. Yogyakarta: Andi Ofset,Edisi Refisi.

HS, H. Salim \& Erlies S.N. (2013). Penerapan Teori Hukum Pada Penelitian Tesis dan Disertasi. Jakarta: PT RajaGrafindo Persada.

Narbuko, C dkk. (1997). Metodologi Penelitian. Jakarta: Bumi Aksara.

ND, Mukti F \& Yulianto. A. (2007). Dualisme Penelitian Hukum. Yogyakarta: Fakultas Hukum Universitas Muhammadiyah.

Rachman, H. A. (2016). Dasar-Dasar Penyiaran. Pekanbaru: Unri Press.

\section{Jurnal}

Firmansyah, M. I. (2016). Studi Deskriptif Tentang Sinergitas Kewenangan Antara BPJS Kesehatan dengan Organisasi Profesi Dalam Penyediaan Layanan Kesehatan di Kota Surabaya. Jurnal Kebijakan dan Manajemen Publik (4) 2.

Prajoko. R. (2020). Membangun Media Penyiaran yang Berdaulat. Intelektiva: Jurnal Ekonomi, Sosial, dan Humaniora (01) 09.

Pranoto, E. (2020). Peran KPI dalam Menjaga Keberagaman. Magistra Law Review (01) 01.

Putri. A.R \& Ellyda. R. (2020). Strategi Komunikasi KPID Jawa Timur Dalam Pencegahan Penyebaran Virus Corona. Jurnal Komunike (12) 2. 


\section{Internet}

kpi.go.id. (2021). Evaluasi Kepatuhan Televisi Atas Protokol Kesehatan Dalam Penyelenggaraan Penyiaran di Masa Pandemi Covid-19: Januari 2021. Available from http://www.kpi.go.id/index.php/id/umum/38dalam-negeri?detail5=936\&detail3=76\&start=70. Diakses 10 Mei 2021 .

kpi.go.id. (2021). Imbauan dan Evaluasi Muatan Siaran di Masa Pandemi Covid19. Available at http://www.kpi.go.id/index.php/id/edaran-dansanksi/35656-imbauan-dan-evaluasi-muatan-siaran-di-masapandemi-covid-19, diakses 14 Mei 2021.

\section{Undang-Undang dan Peraturan Lainnya}

Undang-Undang Republik Indonesia Nomor 32 Tahun 2002 tentang Penyiaran. Lembaran Negara Republik Indonesia Tahun 2002 Nomor 139 dan Tambahan Lembaran Negara Republik Indonesia Nomor 4252.

Peraturan Komisi Penyiaran Indonesia Nomor 01/P/KPI/02/2012 tentang Pedoman Perilaku Penyiaran, Peraturan Komisi Penyiaran Indonesia 02/P/KPI/03/2012 tentang Standar Program Siaran.

Surat Edaran Komisi Penyiaran Indonesia Pusat Nomor 123/K/KPI/31.2/03/2020 tentang Penyiaran Wabah Corona.

Keputusan Komisi Penyiaran Indonesia Pusat Nomor 12 Tahun 2020 tentang Dukungan Lembaga Penyiaran Dalam Upaya Pencegahan dan Penanggulangan Persebaran Covid-19. 